\author{
Asian Journal of \\ Medical and Biological Research \\ ISSN 2411-4472 (Print) 2412-5571 (Online) \\ www.ebupress.com/journal/ajmbr
}

\title{
Article \\ Bacteriological quality of dry powder milk available in local markets of Bangladesh
}

\author{
Nazia Afrin* and RashedaYasmin Shilpi \\ Department of Botany, Jahangirnagar University, Savar, Dhaka-1342, Bangladesh \\ *Corresponding author: Nazia Afrin, Department of Botany, Jahangirnagar University, Savar, Dhaka-1342, \\ Bangladesh. Phone: +8801705071024; E-mail: naziaafrin49@gmail.com
}

Received: 30 August 2018/Accepted: 25 September 2018/ Published: 30 September 2018

\begin{abstract}
Milk and milk powders are very rich in several nutrients and relished by everybody throughout the world. The present study was undertaken with the aim of investigating the bacteriological quality of locally available dry powder milk in Bangladesh. A total number of eight powder milk samples were collected from Gazipur city and its surrounding areas during the period from January 2017 to February 2017. The analysis comprised of enumeration of total viable bacterial count (TVBC), isolation of bacterial isolates and identification of pathogenic bacteria. Almost all the powder milk samples showed the total aerobic heterotrophic bacterial (TAHB) level above the standard acceptable range $\left(>10^{4} \mathrm{CFU} / \mathrm{g}\right)$. Both gram positive and gram negative pathogenic bacteria viz. Staphylococcus aureus, Staphylococcus epidermidis, Bacillus, pseudomonas sp. and Enterobacter sp. were isolated from studied samples through morphological and biochemical characteristics. Pseudomonas sp. were confirmed by API 20E. These results highlighted the necessity to maintain appropriate sanitary and hygienic measures at each critical point in order to safeguard consumers from food borne pathogens.
\end{abstract}

Keywords: pathogenic bacteria; powder milk; commercial local market; identification

\begin{abstract}
1. Introduction
Dairy powders are a popular commodity due to their long shelf life, ease of storage and versatile nature. As milk and dairy products are very rich in several nutrients, they are relished by everybody throughout the world. Variety of dairy powders can be produced such as whole milk powder (WMP), skimmed milk powder (SMP), whey protein concentrate (WPC), whey protein isolate (WPI), milk protein concentrate (MPC), milk protein isolate (MPI), casein and caseinates (Lagrange et al., 2015). Dairy powders can be used in fortification of other dairy products (Karam et al., 2013), as well as an ingredient in a wide array of foods including soups and sauces, confectionary (Sharma et al., 2012), infant formula, sports dietary supplements and in foods for health recovery (Gill et al., 2001; Lagrange et al., 2015). Moreover, the advantages of dry milk over liquid milk are better keeping quality, less storage space, and low shipping costs (Robert et al., 2015). However, when controlling microbial loads of dairy powders, the increased production may create safety and economic risks to the dairy sector.

Milk powder is made by removing water from liquid milk. Removal of water is necessary to reduce water activity for the prevention of microorganism growth. Powder milk has a long shelf life than raw milk. Skim milk powder has a maximum shelf life of about 3 years where as whole milk powder has a maximum shelf life of about 6 months (Flegam and Oluwaniyi, 2015). Now a days, a great emphasis is given on adding value to powder milk. The important quality parameters for milk powder are microbiological quality, and sensory characteristics, beside physical and chemical properties, which are mainly concerned with the content of moisture, fat, total protein, and non-protein nitrogen, lactose, titratable acidity, ash, and other nutrients such as calcium (Laszlo, 2007). The thermophilic organisms have ability to produce extremely heat resistant spores and
\end{abstract}


can have significant economic consequences when they exceed specification limits. Thus, they may result in down grading of the products (Anup and Rupesh, 2012).

Microbial pathogens which are of major concern in dried milk include Bacillus cereus, Staphylococcus aureus and Salmonella. These organisms may remain viable in milk powder for long period of time, and resume growth when the powder is reconstituted and stored at favorable temperature (Hafsa et al., 2013). Study performed in New Zealand for sample of milk powder revealed that it is contaminated by Bacillus licheniformis and Bacillus subtilis (Ronimus et al., 2006). Another study of sample from different countries were examined, the dominated isolate was Anoxybacillus flevithermus followed by Bacillus licheniformis (Rucket et al., 2004).

In our country in Bangladesh, the microbiological quality of dry milk powder is not known. There is no quality control system for the powder milk though they are popularly consumed by all age groups both in urban and rural areas. So, the present study was undertaken to assess the microbiological quality of powder milk, enumeration of the bacterial load, isolation and identification of the pathogenic bacteria from powder milk samples.

\section{Materials and Methods \\ 2.1. Sample collection}

Eight powder milk samples were collected from different local market of Gazipur city and its surrounding area. The packets were cleaned by washing with sterile water followed by rubbing with $95 \%$ alcohol and opened in the laminar air flow using sterile scissors. All packaged samples were maintained with their expiration dates. The samples were preserved at $4^{\circ} \mathrm{C}$ for detailed study.

\subsection{Isolation of bacteria}

Bacterial enumeration and isolation was carried out by spread plate method in Nutrient Agar media (NA) (Eklund and Lankford, 1967) at adjusted pH 6. The microbiological condition of safety and hygiene were then assayed using the methods recommended by International Commission on Microbiological Specifications for Foods (ICMSF, 2005). The sample $(0.1 \mathrm{ml})$ of each dilution was taken onto each sterile petridish and evenly spread on the solid nutrient medium and incubated at $37^{\circ} \mathrm{C}$ for 24 hours. After incubation, plates having well discrete colonies were selected for counting. Discrete bacterial colonies were isolated immediately after counting. Based on distinct colony morphology, further selection was made and isolates were purified by repeated streaking as well as stored in NA slants at $4^{\circ} \mathrm{C}$ for further analysis.

\subsection{Microbial load determination}

Microbial load was determined from the total number of discrete colonies counted after incubation. Isolated colonies were counted in colony formation unit (CFU per gram) as follows-Number of CFU/ $g=$ Number of $\mathrm{CFU} /$ (Volume plated in $\mathrm{ml} \times$ total dilution used)

\subsection{Identification of the isolates}

The selected bacterial colonies were observed to study various characters viz. color, form, elevation, margin, surface, optical characters etc. according to Eklund and Lankford (1967). Bacterial colonies were cultured on different selective and differential media such as: MSA, SSA, EMB, MacConkey, Bouillon agar, King's B, Simon citrate etc. Different biochemical tests (Casein test, Fermentation test, Indole test, Starch hydrolysis test, Catalase test etc.) were also performed. Results of the physiological and biochemical tests of selected isolates were analyzed following Bergey's Manual of Systematic Bacteriology (Sneath et al., 1986), Bergey's Manual of Determinative Bacteriology (Buchanan et al., 1974), Manual of Microbiological Methods (SAB, 1957), Microbiological Methods (Collins et al., 1984) and Understanding Microbes (Claus, 1995). Coagulase test, endospore staining and API $20 \mathrm{E}$ (Holmes et al., 1978) were used as a confirmation test of bacterial genus or species of Staphylococcus aureus, Bacillus sp. and Pseudomonas sp.

\section{Results}

A total of 24 bacterial isolates was obtained from powder milk samples. Mean heterotrophic bacterial load of the milk samples were ranged from $9.9 \times 10^{3}$ to $32.7 \times 10^{4} \mathrm{CFU} / \mathrm{g}$ on Nutrient Agar media. In case of powder milk, maximum heterotrophic bacterial counts were observed in the Sample-3 (Table1). While minimum heterotrophic bacterial counts were observed in the Sample-8 (Table1). According to guidelines elaborated by the International Commission on Microbiological Specifications for Foods (ICMSF, 2005), the total bacterial count in powder milk below $10^{4} \mathrm{CFU} / \mathrm{g}$ is indicative of their acceptable quality, the counts of $10^{4}$ to $10^{5} \mathrm{CFU} / \mathrm{g}$ indicates their permissible quality, whereas bacterial count exceeding $10^{5} \mathrm{CFU} / \mathrm{g}$ is unacceptable. In view of 
these guidelines, CFU results showed marginally acceptable quality of the analyzed milk samples (Table1). All the powder milk samples exceeded the acceptable limits except one. But none of them exceeded the unacceptable limit.

In the present study, Staphylococcus aureus (Plate1B), Staphylococcus epidermidis (Plate1B), Bacillus sp., Enterobacter sp. and Pseudomonas sp. were identified through their respective color in specific culture media. In addition, results of biochemical tests (Table3) of different isolates revealed that out of 24 isolates 18 isolates were gram positive while the rest were gram negative (Plate1D) and rod shaped. Among the gram-positive isolates 12 were cocci (Plate1C) and 6 were rod shaped. All the isolates were catalase positive, casein negative, lactose fermentation negative and indole negative. Out of 24 isolates only 8 isolates were positive in starch hydrolysis test (Plate1E) and 6 were positive in endospore staining which showed the presence of Bacillus sp. Only 6 isolates showed positive result in citrate test (Plate1F). Among 12 cocci shaped bacteria 9 were positive for coagulase test which confirmed the presence of Staphylococcus aureus. API 20 E test confirmed the presence of Pseudomonas sp.

Table 1. Bacterial load of different samples.

\begin{tabular}{llll}
\hline Samples & CFU (average) & $\mathbf{m}^{*}$ & $\mathbf{M}^{*}$ \\
\hline Sample-1 & $25 \times 10^{4}$ & & \\
Sample-2 & $22 \times 10^{4}$ & & \\
Sample-3 & $32.7 \times 10^{4}$ & & \\
Sample-4 & $8.3 \times 10^{4}$ & $10^{4}$ & $10^{5}$ \\
Sample-5 & $19.9 \times 10^{4}$ & & \\
Sample-6 & $15.3 \times 10^{4}$ & & \\
Sample-7 & $3.4 \times 10^{4}$ & & \\
Sample-8 & $9.9 \times 10^{3}$ & & \\
\hline
\end{tabular}

*m, acceptable level and values above it are marginally acceptable or unacceptable in the terms of the sampling plan and *M, a microbiological criterion which separates marginally acceptable quality from defective quality according to ICMSF. Bacterial load represents as CFU/g

Table 2. Bacterial isolates on different selective and differential media.

\begin{tabular}{|c|c|c|c|c|c|c|c|c|}
\hline $\begin{array}{l}\text { Bacterial } \\
\text { isolates }\end{array}$ & MSA & EMB & $\begin{array}{l}\text { Mac- } \\
\text { conkey }\end{array}$ & SSA & Bouillon & $\begin{array}{l}\text { Simon } \\
\text { citrate }\end{array}$ & Kings $B$ & BGA \\
\hline PP 1 & $\mathrm{NG}$ & Colorless & Pink & Pink & White & Blue & White & NG \\
\hline PP 2 & $\mathrm{NG}$ & $\mathrm{NG}$ & Pink & NG & White & Blue & White & NG \\
\hline MP 3 & Yellow & Colorless & NG & NG & White & NG & White & NG \\
\hline MP 4 & NG & Colorless & NG & NG & White & NG & White & NG \\
\hline FP 5 & NG & Colorless & Colorless & NG & White & $\mathrm{NG}$ & Greenish Yellow & NG \\
\hline FP 6 & Pink & NG & NG & NG & White & NG & White & NG \\
\hline MP 7 & Yellow & NG & NG & NG & White & NG & White & NG \\
\hline DD 1 & NG & Colorless & Pink & Pink & White & Blue & White & NG \\
\hline DD 2 & NG & NG & Pink & NG & White & Blue & White & NG \\
\hline DD 3 & $\mathrm{NG}$ & $\mathrm{NG}$ & $\mathrm{NG}$ & NG & White & $\mathrm{NG}$ & White & NG \\
\hline DD 4 & Yellow & $\mathrm{NG}$ & $\mathrm{NG}$ & NG & White & $\mathrm{NG}$ & White & NG \\
\hline DD 5 & NG & NG & Pink & NG & White & Blue & White & NG \\
\hline NP 1 & Pink & NG & NG & NG & White & NG & White & NG \\
\hline NP 2 & Yellow & $\mathrm{NG}$ & $\mathrm{NG}$ & NG & White & NG & White & NG \\
\hline NP 3 & Yellow & NG & NG & NG & White & NG & White & NG \\
\hline NP 4 & NG & NG & $\mathrm{NG}$ & NG & White & NG & White & NG \\
\hline NP5 & NG & $\mathrm{NG}$ & $\mathrm{NG}$ & NG & Off white & NG & White & NG \\
\hline NP 6 & $\mathrm{NG}$ & NG & $\mathrm{NG}$ & NG & Off white & NG & White & NG \\
\hline NP 7 & $\mathrm{NG}$ & $\mathrm{NG}$ & $\mathrm{NG}$ & NG & Off white & $\mathrm{NG}$ & White & NG \\
\hline NP 8 & Yellow & Colorless & $\mathrm{NG}$ & NG & White & NG & White & NG \\
\hline NP 9 & Yellow & NG & $\mathrm{NG}$ & NG & White & NG & White & NG \\
\hline NP10 & Yellow & NG & $\mathrm{NG}$ & NG & White & NG & White & NG \\
\hline NP11 & Pink & $\mathrm{NG}$ & $\mathrm{NG}$ & NG & White & $\mathrm{NG}$ & White & NG \\
\hline NP12 & Yellow & NG & $\mathrm{NG}$ & NG & White & $\mathrm{NG}$ & White & NG \\
\hline
\end{tabular}

NG* No Growth 
Table 3. Biochemical characteristics of the bacterial isolates.

\begin{tabular}{lllllllll}
\hline Isolates & $\begin{array}{l}\text { Catalase } \\
\text { test }\end{array}$ & $\begin{array}{l}\text { Casein } \\
\text { test }\end{array}$ & $\begin{array}{l}\text { Fermentation } \\
\text { test }\end{array}$ & $\begin{array}{l}\text { Indole } \\
\text { test }\end{array}$ & $\begin{array}{l}\text { Starch } \\
\text { hydrolysis }\end{array}$ & $\begin{array}{l}\text { Gram } \\
\text { staining }\end{array}$ & $\begin{array}{l}\text { Endospore } \\
\text { staining }\end{array}$ & $\begin{array}{l}\text { Coagulase } \\
\text { test }\end{array}$ \\
\hline PP 1 & + & - & - & - & - & - & NA & NA \\
PP 2 & + & - & - & - & + & - & NA & NA \\
MP 3 & + & - & - & - & + & + & - & + \\
MP 4 & + & - & - & - & + & + & + & NA \\
FP 5 & + & - & - & - & - & - & NA & - \\
FP 6 & + & - & - & - & - & + & - & + \\
MP 7 & + & - & - & - & + & + & - & NA \\
DD 1 & + & - & - & - & + & - & NA & NA \\
DD 2 & + & - & - & - & - & - & + & + \\
DD 3 & + & - & - & - & + & + & + & NA \\
DD 4 & + & - & - & - & + & + & - & + \\
DD 5 & + & - & - & - & - & - & NA & + \\
NP 1 & + & - & - & - & - & + & - & - \\
NP 2 & + & - & - & - & - & + & - & - \\
NP 3 & + & - & - & - & - & + & - & + \\
NP 4 & + & - & - & - & - & + & + & + \\
NP5 & + & - & - & - & - & + & + & + \\
NP 6 & + & - & - & - & - & + & + & + \\
NP 7 & + & - & - & - & + & + & + & + \\
NP 8 & + & - & - & - & - & + & - & + \\
NP 9 & + & - & - & - & - & + & - & + \\
NP10 & + & - & - & - & - & + & - & - \\
NP11 & + & - & - & - & - & + & - & + \\
NP12 & + & - & - & - & - & + & - & + \\
\hline
\end{tabular}

*NA - Not Available
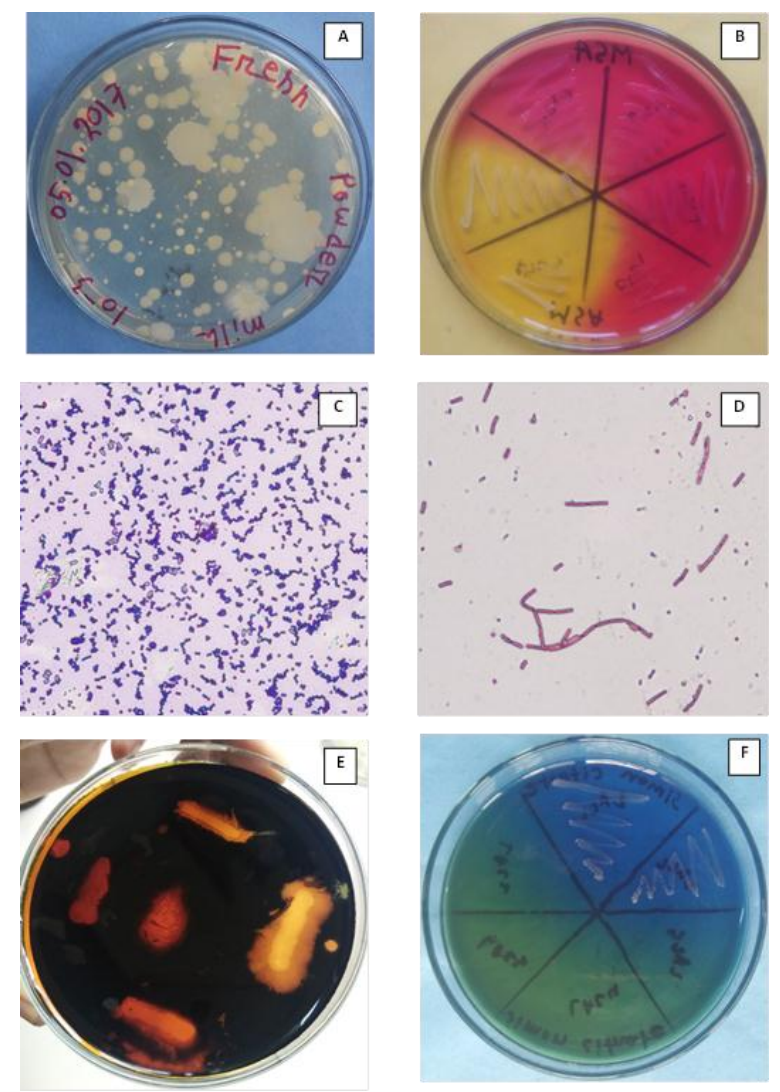

Plate 1. Bacterial colonies on nutrient agar (A), Staphylococcus aureus (yellow colonies) and $S$. epidermidis (pink colonies) on MSA media (B), gram staining represents gram positive (cocci shaped) $S$. aureus (C) and rod shaped gram negative Enterobacter (D), starch hydrolysis test (E), Simon citrate test (F). 


\section{Discussion}

The knowledge of microbes and their evolution is highly imperative to ensure safety and quality of dairy products (Ahmed et al., 2014). Numerous studies have documented that powder milk could be contaminated by bacteria. The microbial count of dried milk powder has been reported by Salahudin and Naural (2006). Common contaminants identified in dairy powders include species of Bacilli, many of which are capable of forming endospores (Checinska et al., 2015). Taxa other than Bacilli have also been found to contaminate powdered dairy products includes Clostridium halophilum, Klebsiella oxytoca (Buehner et al., 2015), C. perfringens, C. septicum, C. novyi/haemolyticum, C. sporogenes (Barash et al., 2010), Staphylococcus aureus (Zhang et al., 2015), and Cronobacter sakazakii (Minami et al., 2012). These findings are in agreement to our study where we identified Staphylococcus aureus, S. epidermidis, Enterobacter sp., Pseudomonas sp. and Bacillus sp. from different samples. Similar finding was also reported by Hafsa et al. (2013). Pal (2011) identified Staphylococcus aureus which can be present in the cow's udder and teats, and consequently contaminate the milk.

The sources of microbial contamination of dry milk powder are many. Microorganisms that contaminate powder milk may come from air, dust, soil, water, insects, humans, storage containers and handling and processing equipment. Bacteria can originate from the soil (Heyndrickx, 2011), feces, bedding, feed, or milking equipment (Gleeson et al., 2013), or can enter the raw milk via contaminated teats, milking cups and bulk tanks. Additionally, contamination can occur during transport from the farm to the processing plant (Pantoja et al., 2011), and also within the processing facility itself from poor handling and contaminated equipment (Burgess $e t$ al., 2010; Faille et al., 2014). High numbers of microorganisms in the raw milk may result high numbers in the milk powder, and the decline in numbers as a result of exposure to heat, is offset by the removal of water in the powder (Ron et al., 2006). Thus, improper cleaning and sanitation of dairy equipments will lead to food poisoning due to contamination by microbes (Pal and Mahendra, 2015). In addition, the formation of homogeneous or heterogeneous multicellular bacterial communities on the surface of processing equipment in the form of biofilms is a particular concern for the dairy processing sector and, when present, can lead to recurring problems of microbial contamination (Branda et al., 2001; Faille et al., 2014).

On the other hand, it has been shown that the spore-forming bacterial composition of raw milk differs considerably from their associated dairy powders (Miller et al., 2015), highlighting that the processing of milk into powder changes the composition of the specific spore-formers present. Post-production, powders can be stored for extended periods and in the absence of water, bacterial metabolic activity and growth is limited (Deng et al., 2012), thus preventing spoilage and product defects. However, under these conditions, bacterial spores can remain dormant until more favorable conditions are encountered, when germination and outgrowth can proceed (Setlow, 2003, 2014). In spray-drying the amount of heating to which contaminating bacteria may be exposed are insufficient for the drying process to decontaminate the milk even in respect of relatively heatsensitive pathogens such as Salmonella. Besides, post-processing contamination of the powder milk from food production environments occur. Therefore, milk for spry-drying should be pasteurized first and care should be taken that there is no possibility of recontamination between pasteurizer and drier (Harrigan, 1998).

\section{Conclusions}

From the present study it can be concluded that dry powder milk can be frequently contaminated by pathogenic and spore forming bacteria. Both pre pasteurization and post pasteurization contamination occur. Therefore, low cost, simple and easy methods should be developed to detect the spoilage producing bacteria in milk and milk products. Such methods would be very beneficial to poor resource countries like Bangladesh. All milk and liquid product should be pasteurized prior to concentration before drying and post processing contamination should be checked. Finally, it is imperative to monitor every step of food production, from handling of raw products to preparation of finished foods in order to protect consumers from food borne illness.

\section{Acknowledgements}

The authors would like to thank to Md. Shakhawate Hossain for his critical review of the manuscript.

\section{Conflict of interest}

None to declare.

\section{References}

Ahmed MMM, EE Hafez, MH Mona, AA Hagar and YM Mabrouk, 2014. Detection of baby milk powder contamination by microorganisms. W. App. Sci. J., 1: 93-98. 
Anup S, HJ Atanuand SC Rupesh, 2012. Functionality of milk powders and milk based powders for end user applications. Compr. Rev. Food Sci. Food Saf., 11: 1-11.

Barash JR, JK Hsia and SS Arnon, 2010. Presence of soil-dwelling Clostridia in commercial powdered infant formulas. J. Pediatr., 156: 402-408.

Branda SS, JE Gonzalez-Pastor, S Ben-Yehuda, R Losick and R Kolter, 2001. Fruiting body formation by Bacillus subtilis. Proc. Natl. Acad. Sci. U.S.A., 98: 11621-11626.

Buchanan RE and NE Gibbons, 1974. Bergey's Manual of Determinative Bacteriology ( $8^{\text {th }}$ ed.). The Williams and Wilkins Company, USA. pp. 1268.

Buehner KP, S Anand and GD Djira, 2015. Prevalence of thermoduric bacteria and spores in nonfat dry milk powders of Midwest origin. J. Dairy Sci., 98: 2861-2866.

Burgess SA, D Lindsayand SH Flint, 2010. Thermophilic bacilli and their importance in dairy processing. Int. J. Food Microbiol., 144: 215-225.

Checinska A, A Paszczynski and M Burbank, 2015. Bacillus and other spore-forming genera: variations in responses and mechanisms for survival. Annu. Rev. Food Sci. Technol., 6: 351-369.

Claus GW, 1995. Understanding microbes ( $4^{\text {th }}$ ed.). W.H. Freeman and Company, New York. pp. 547.

Collins CH and Lyne PM, 1984. Microbiological methods (5th ed.). Butter worth and Co. Publisher Ltd, London. pp. 448.

Deng X, Li Z and W Zhang, 2012. Transcriptome sequencing of Salmonella enterica serovar Enteritidis under desiccation and starvation stress in peanut oil. Food Microbiol., 30: 311-315.

Eklund C and CE Lankford, 1967. Laboratory manual for general microbiology. Prentice-Hall International Inc., London. pp. 299.

Faille C, T Benezech, G Midelet-Bourdin, Y Lequette, M Clarisse and G Ronse, 2014. Sporulation of Bacillus spp. within biofilms: a potential source of contamination in food processing environments. Food Microbiol., 40: 64-74.

Falegan CR and TT Oluwaniyi, 2015. Microbial composition, antibiotic sensitivity and proximate composition of popular imported powdered infant milk formulas sold in Ado Ekiti, Nigeria. Int. J Microbiol. Gen. Mol. Biol. Res., 1: 10-24.

Gill HS, KJ Rutherfurd and ML Cross, 2001. Dietary probiotic supplementation enhances natural killer cell activity in the elderly: an investigation of age-related immunological changes. J. Clin. Immunol., 21: 264271.

Gleeson D, A O'Connell and K Jordan, 2013. Review of potential sources and control of thermoduric bacteria in bulk-tank milk. Irish J. Agric. Food Res., 52: 217-227.

Hafsa A, S Fouzia, MD Fakruddin, Kamrunnahar, UMK Zahed and D Suvamoy, 2013. Isolation of Escherichia coli and Staphylococcus aureus from full cream powder milk sold under market conditions at Dhaka, Bangladesh and their antibiotic susceptibility. J. Adv. Sci. Res., 4: 27-31.

Heyndrickx M, 2011. The importance of endospore-forming bacteria originating from soil for contamination of industrial food processing. Appl. Environ. Soil Sci., Article ID 561975, 11 pages.

Holmes B, WR Willcox and SP Lapage, 1978. Identification of Enterobacteriaceae by the API 20E system. J. Clinical Path., 31: 22-30.

ICMSF, 2005. Spices, herbs and vegetable seasonings. In: ICMSF (International Commission on Microbiological Specifications for Foods) (Ed.), Microorganisms in Foods, Microbial Ecology of Food Commodities. Kluwer Academic/Plenum Publishers, London. pp. 360-372.

Jay JM, 1970. Modern food microbiology. New York. Van Nostr and Reinhold.

Karam MC, C Gaiani, C Hosri, J Burgain and J Scher, 2013. Effect of dairy powders fortification on yogurt textural and sensorial properties: a review. J. Dairy Res., 80: 400-409.

Lagrange V, D Whitsett and C Burris, 2015. Global market for dairy proteins. J. Food Sci., 80: 16-22.

László V, 2007. Microbiological quality of commercial dairy products. Appl. Microb., 1: 1-8.

Miller RA, DJ Kent, MJ Watterson, KJ Boor, NH Martin and M Wiedmann, 2015. Spore populations among bulk tank raw milk and dairy powders are significantly different. J. Dairy Sci., 98: 8492-8504.

Minami J, T Soejima, T Yaeshima and K Iwatsuki, 2012. Direct real-time PCR with ethidium monoazide: a method for the rapid detection of viable Cronobacter sakazakii in powdered infant formula. J. Food Prot., 75: 1572-1579.

Pal M, 2001. Epidemiology of staphylococcal food poisoning. Beverage and Food World, 28: 11-13.

Pal M and R Mahendra, 2015. Sanitation in Food Establishments. Lambert Academic Publishing, Saarbruchen, Germany. 
Pal M and VJ Jadhav, 2013. Microbial contamination of various Indian milk products. Beverage and Food World, 40: 43-44.

Pantoja JC, DJ Reinemann and PL Ruegg, 2011. Factors associated with coliform count in unpasteurized bulk milk. J. Dairy Sci., 94: 2680-2691.

Reves FJ, HJ Bastias, RM Gutierrez and LMde Rodriguez, 2007. Prevalence of Bacillus cereus in dried milk products used by Chilean School Feeding Program. J. Food Microbiol., 24: 1-6.

Robert MK, FF Gerald, H Colin, S Catherine and RR Paul, 2015. Novel approaches to improve the intrinsic microbiological safety of powdered infant milk formula. Nutrients, 7: 1217-1244.

Ron SR, RK Andreas and WM Hugh, 2006. Survival of thermophilic spore-forming bacteria in a $90+$ year old milk powder from Ernest Shackelton's Cape Royds Hut in Antarctica. J. Dairy Res., 73: 235-243.

Ronimus SR, A Ruckert and WH Morgan, 2006. Survival of thermophilic spore-forming bacteria in a 90+ year old milk powder from Ernest Shackelton's Cape Royds Hut in Antarctica. J. Dairy Res., 73: 235-243.

Ruckert AS, R Ronimus and WH Morgan, 2004. Based survey of thermophilic bacilli in milk powders from different countries. Int. J. Food Micrbiol., 96: 263 -272.

SAB (Society of American Bacteriologists), 1957. Manual of microbiological methods. McGraw Hill Inc., New York. pp. 315.

Salahudin A and AM Nural, 2006. Microbial counts of dried powder milk available in local markets of Bangladesh. Ban. J. Microbiol., 23: 162-164.

Setlow P, 2003. Spore germination. Curr. Opin. Microbiol., 6: 550-556.

Setlow P, 2014. Germination of spores of Bacillus species: what we know and do not know. J. Bacteriol., 196: $1297-1305$.

Sharma A, AH Jana and RS Chavan, 2012. Functionality of milk powders and milk-based powders for end use applications-a review. Compr. Rev. Food Sci. Food Saf., 11: 518-528.

Sneath PHA, NS Mair, ME Sharpe, JG Holt, C Frank, R Prager, W Rabsch, S Broll and F Feil, 1986. Bergey's manual of systematic bacteriology ( $9^{\text {th }}$ ed.), vol. 2. Williams and Wilkins. Baltimore, London. pp. 1599.

Zhang Z, W Liu, H Xu, ZP Aguilar, NP Shah and H Wei, 2015. Propidium monoazide combined with realtime PCR for selective detection of viable Staphylococcus aureus in milk powder and meat products. J. Dairy Sci., 98: 1625-1633. 